\title{
Effect of Turbine and Compressor Inlet Temperatures and Air Bleeding on the Comparative Performance of Simple and Combined Gas Turbine Unit
}

\author{
Basharat Salim, Jamal Orfi and Shaker Saeed Alaqel
}

\begin{abstract}
The proper utilization of all the available forms of energy resources has become imminent to meet the power requirement and energy demand in both the developed and developing countries of the world. Even though the emphasis is given to the renewable resources in most parts of the world, but fossil fuels will still remain the main resources of energy as these can meet both normal and peak demands. Saudi Arab has number of power plant based on natural gas and fuel that are spread in all its regions. These power plants have aeroderivative gas turbine units supplied by General Electric Company as main power producing units. These units work on dual fuel systems. These units work as simple gas turbine units to meat peak demands and as part of combined cycle otherwise. The subject matter of this study is the performance of one of the units of a power plant situated near Riyadh city of Saudi Arab. This unit also works both as simple gas turbine unit and as a part of combined cycle power plant unit. A parametric based performance evaluation of the unit has been carried out to study both energetic and exergetic performance of the unit for both simple and combined cycle operation. Effect of compressor inlet temperature, turbine inlet temperature, pressure ratio of the compressor, the stage from which bleed off air have been taken and percentage of bleed off air from the compressor on the energetic and exergetic performance of the unit have been studied. The study reveals that all these parameters effect the performance of the unit in both modes of operation.
\end{abstract}

Index Terms - Energetic Efficiency, Exergetic Efficiency, Aeroderivative Turbines, Air Bleeding, Compressor Inlet Temperature, Turbine Inlet Temperature.

\section{INTRODUCTION}

Gas turbines plays a key role in power generation market. These produce clean, efficient, affordable, and fuel-flexible electric power. Gas turbine plants are used for production of electricity in most of the countries of the world because of their low capital cost, short synchronization time and grid stability Jabber, et al [1]. Working on the basis of Brayton cycle, conventional gas turbine cycle consists an axial compressor for pressurizing air followed by combustion chamber for combustion of the fuel in presence of air. The energy released from the fuel is absorbed by air. The heated air is then expanded in an axial turbine, where the energy transformation takes place from thermal energy of working fluid to mechanical energy of shaft rotation that is connected to generator to produce electrical power (Fig. 1).

Published on December 14, 2020.

Basharat Salim, Department of Mechanical Engineering, College of Engineering, King Saud University, Saudi Arabia.

(corresponding e-mail: basharat ${ }^{\circledR}$ ksu.edu.sa)

Jamal Orfi, Department of Mechanical Engineering, College of Engineering, King Saud University, Saudi Arabia.

(e-mail: orfij@ksu.edu.sa)

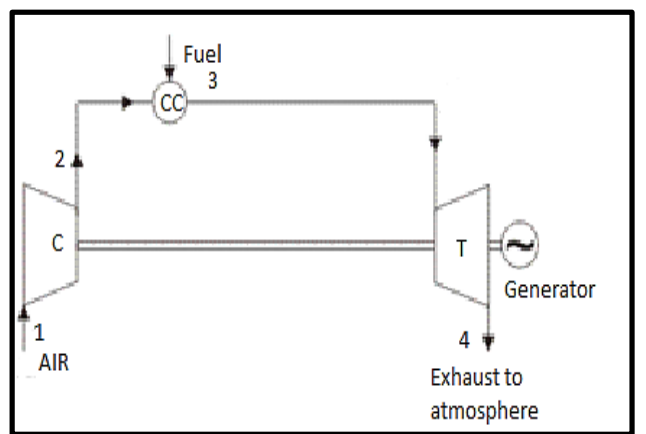

Fig. 1. Basic Gas Turbine Components.

The efficiency of the cycle is maximum when turbine inlet temperature is maximum. Maximum temperature can occur when fuel- air mixture is burned under stoichiometric conditions. The turbine inlet temperature (TIT) has increased from $700{ }^{\circ} \mathrm{C}$ in 1950 to about $1700{ }^{\circ} \mathrm{C}$. The use of advanced material technology and cooling of turbine blades by bleeding off air from compressor to the turbine blades has caused this jump in TIT. A fraction of the air from the compressor is bled off as cooling air which is utilized for cooling turbine blades. The air is extracted from the compressor at appropriate pressures depending upon where it is utilized in the turbine.

\section{MAterial AND MethodS}

Despite advantages of gas turbines to generate power one cannot disregard the huge quantities of hot exhausted gases produced that contains almost two thirds of the chemical energy of fuel consumed which results in environmental degradation in that area. The cogeneration of electricity and desalination of water improves the utilization of such energy and minimizes the release of high temperature effluents to the environment. Brayton Cycle and Rankine Cycle complement each other to form efficient combined cycles (Fig. 2). The combined-cycle systems provide flexibility with varied features for different usage. This results in better utilization of input energy to the plants and diminishes the environmental impact of these plants. It produces steam that can be used in a process (cogeneration) or used to drive a steam turbine (combined cycle). The efficiency of such plants rises from $20 \%$ for pure gas turbines to $60 \%$ for combined plants and $80 \%$ for cogeneration units Najjar [2].

Shaker Saeed Alaqel, Department of Mechanical Engineering, College of Engineering, King Saud University, Saudi Arabia.

(e-mail: shaker_alaqel@ ${ }^{@}$ windowslive.com) 


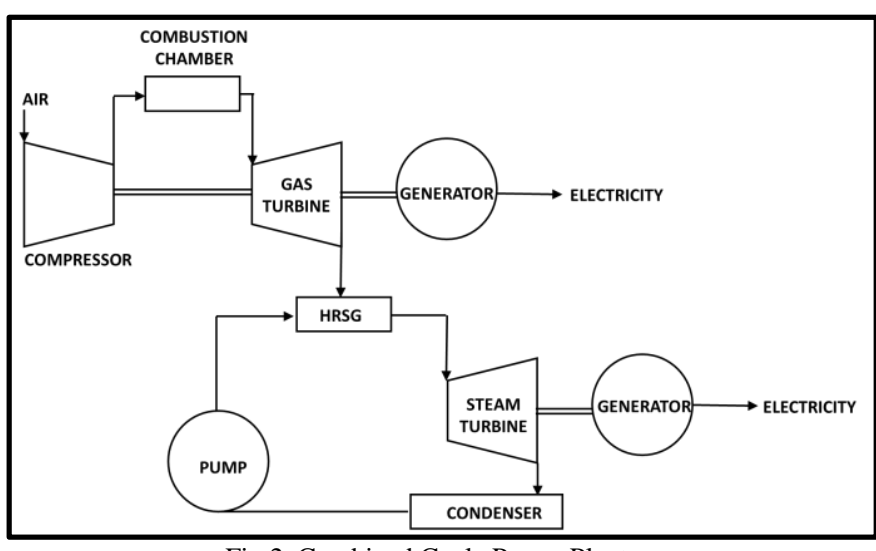

Fig 2. Combined Cycle Power Plant.

Gas turbine plants operating in an open or simple cycle have relatively high unit cost of generated electricity and low efficiencies, Jabber, et al [3]. The average efficiency of a gas turbine peaking plants is in the range of $20-28 \%$, Abdurrahman and Abdulhadi [4]. Unit cost of electricity could be reduced by power augmentation techniques such as cooling the air at the compressor intake which helps increasing the density of air flowing into the plant and thereby increasing the power generated by it. The ambient temperature has a strong influence on the gas turbine performance. Generally, unlike the heat rate, the net power output form a gas turbine decreases with the increase of the ambient air temperature. The ambient temperature has a strong influence on the gas turbine performance [5], [6] and [2]. A $25 \%$ loss of the rated power capacity of the gas turbine at ISO conditions has been reported, Amel and Cadavid [7] when the ambient temperature reaches $40{ }^{\circ} \mathrm{C}$. Al-Bortmany [8] has shown that an increase in power production up to 20 $\%$ in winter and $40 \%$ in summer is possible if the inlet temperature of a gas turbine power plant unit is decreased to $7{ }^{\circ} \mathrm{C}$.

Unit cost of produced electricity and gaseous emissions that would otherwise arises from conventional generators could be reduced by employing a hybrid system that uses a renewable energy source, such as, solar energy or by using advanced technologies, such as, regenerative cycle, combined cycle and power augmentation, Jabber, et al [9]. Many studies have been carried out to evaluate the performance of combined cycles. These include the studies that intend to maximize the power output from these cycles Amel and Cadavid [7], and those that address the economic optimization of the system, Franco and Casarosa [10]. Even the ecological features of these plants have also been addressed, Villella and Silvana [11]. Godoy, et al. [12]. has shown a methodology of covering most of these aspects for a simple HRSG system.

Ogaji [13] utilized first law to develop a computer simulation model for investigating the performance of various gas turbine cycles. Pankaj [14] verified the impact of high ambient air temperature on the performance of various gas turbine models utilizing performance data obtained for each model as a basis for comparison and proposed the Earth Tube Heat Exchanger (ETHE) technology as the most effective and economical inlet air cooling method. Somkiat and Pichai [15] performed an exergy evaluation of a combined steam and gas turbine plant to quantify exhaust loss and its effect on the environment. Mohamad and Mofid [16] performed an exergy analysis of a regenerative gas turbine cycle to identify sources of performance loss in the plant. Naser [17] compared various modified Brayton cycles with a regenerative, two-isothermal heat addition Brayton cycle using second law analysis. Kamal and Zuhair [18] investigated the technical and economic feasibility of using turbine inlet air cooling and its effect on the performance of gas turbines in Khartoum which is a high ambient temperature and dusty area and proposed wetted media evaporative cooling to be the most economically feasible option for improving the performance of gas turbine plants in the area. Tamer [19] determined the optimum design parameters of a Brayton- Heat Recovery Steam Generator (HRSG) cycle at maximum exergy and their effects on the exegetic efficiency. Sanjay et al [20] utilized exergy analysis principles and a computer code to emulate the performance of a Brayton - diesel cycle. Ashok et al. [21] combined the first and second law analysis to develop a design methodology for parametric study and thermodynamic performance evaluation of a closed Brayton cycle with Heat Recovery Steam Generator (HRSG).

Rosen and Dincer [22] have qualitatively discussed the relation between exergy efficiency, sustainability and environmental impact. It is seen that with the increase in exergy efficiency the sustainability increases whereas environmental impact decreases. Haseli, et. al. [23] have carried out exergy analysis of Brayton cycle, Rankine cycle and Otto Cycle. They have also shown environmental impact and sustainability for Brayton and Rankine cycle. Saleh, et. al. [24] have carried out a comparative study using mass and energy balances and cost analysis of several cooling technologies coupled with a typical gas turbine under Riyadh weather conditions

The Saudi Electrical Company mostly uses aero derivative GE MS7001EA units for power generation both as simple gas turbine units at peak hours or as a unit of combined cycle for rest of the day. Power plant 9 which is situated near Riyadh has 56 such units. The subject matter of this study is energetic and exergetic analysis of a power plant unit both when working on Brayton cycle and Brayton-Rankine cycle. The detailed performance data of these units at different inlet temperatures for the compressor was procured from the power plant. Tables 1 give basic characteristic of these units. The units run at $3600 \mathrm{rpm}$ and the analysis of the table shows that the mean heating value of the fuel used in these units is $40800 \mathrm{~kJ} / \mathrm{kg}$ approximately. The units have 17 staged axial compressor, 10 symmetrical placed cane annular combustion chambers and 3 stage axial compressor. The results have been presented as a variation of energetic and exergetic efficiencies with compressor inlet temperature for different turbine inlet temperatures, pressure ratio of compressor. Besides this effect of bleed off air from the compressor to be used in turbine cooling and performance of heat recovery unit has also been shown. 
TABLE 1: BASIC PARAMETERS OF THE GAS TURBINE UNIT PARAMETER (UNITS) Inlet Loss $(\mathrm{kPa})$ VALUES 93.63

0.416

Static Pressure at Compressor Inlet $(\mathrm{kPa})$

Static Pressure at Compressor Exit $(\mathrm{kPa}$

Compressor Pressure Ratio CPR

Ambient Static Temperature ${ }^{0} \mathrm{C}$

Static Temperature at Compressor Inlet ${ }^{0} \mathrm{C}$

Static Temperature at Compressor Inlet ${ }^{0} \mathrm{C}$

Mass Flow Rate of Fuel (kg/s)

Static Temperature at Turbine Inlet ${ }^{0} \mathrm{C}$

Static Temperature at Turbine Exit ${ }^{0} \mathrm{C}$

Net Power Output $(\mathrm{kW})$ $\mathrm{Rpm}$

mean heating value of the fuel $(\mathrm{kJ} / \mathrm{kg})$

\section{MATHEMATICAL MODELLING}

The mathematical modelling of the gas turbine unit and combined cycle unit has been carried out using the analysis of Abam and Moses [25] and Haseli, et.al. [23]. The bleed off performance has been developed using Dixon and Hall [5] and Saravanamuttoo, et. al. [26].

\section{A. Normal Functioning of Power Plant Unit}

Efficiency of compressor:

$$
\eta_{c}=\frac{T_{2 s}-T_{1}}{T_{2}-T_{1}}=\frac{\left(\frac{P_{2}}{P_{1}}\right)^{\frac{k-1}{k}}-1}{\frac{T_{2}}{T_{1}}-1}
$$

Efficiency of turbine:

$$
\eta_{t}=\frac{T_{3}-T_{4}}{T_{3}-T_{4 s}}=\frac{1-\frac{T_{4}}{T_{3}}}{1-\left(\frac{P_{4}}{P_{3}}\right)^{\frac{k-1}{k}}}
$$

Compressor Work input:

$$
W_{c}^{\cdot}=\frac{c_{p a} \times m_{a} \times\left(T_{2}-T_{1}\right)}{\eta_{c}}
$$

Turbine Work output:

$\dot{W}_{t}=c_{p g} \times \dot{m}_{g} \times \eta_{t} \times\left(T_{3}-T_{4}\right)$

Steam turbine work output:

$$
\dot{W}_{s}=\dot{m}_{s} \times\left(h_{7}-h_{8}\right)
$$

Work output of gas turbine power plant:

$$
\dot{W}_{G}=\dot{W}_{t}-\dot{W}_{c}
$$

Work output of Combined cycle power plant:

$\dot{W}_{C}=\dot{W}_{t}-\dot{W}_{c}+\dot{W}_{S}$

Total heat input:

$\dot{Q}_{J}=\dot{m}_{f} \times q_{i}$

Energetic efficiency of gas turbine unit:
$=\eta_{1}=\frac{\dot{W}_{G}}{\dot{Q}_{J}}$

Energetic efficiency of combined cycle turbine unit:

$\eta_{1}=\frac{\dot{W}_{c c}}{\dot{Q}_{J}}$

Exergetic efficiency of gas turbine unit:

$$
\eta_{2}=\frac{\dot{W}_{G}}{\chi}=\frac{\dot{W}_{G}}{\left(1-\frac{T_{0}}{T_{k}}\right) \dot{Q}_{J}}
$$

Exergetic efficiency of Combined cycle unit:

$$
\eta_{2}=\frac{\dot{W}_{c c}}{\chi}=\frac{\dot{W_{c c}}}{\left(1-\frac{T_{0}}{T_{k}}\right) \dot{Q}_{J}}
$$

\section{B. Bleed Off Air Mode of Power Plant Unit}

The bleed off performance of the gas turbine unit is based on the assumption that the temperature rise is equal in the stages of the compressor. The work input to the compressor is divided into two parts, one before the bleed off stage and other after the bleed off stage. Therefore, pressure ratio before the bleed off stage and after the bleed off stage are evaluated. This gives a change in the power output of the unit for both simple gas turbine and combined cycle configurations.

$$
\begin{aligned}
& \frac{P_{016}}{P_{01}}=\frac{P_{016}}{P_{0 x}} \times \frac{P_{0 x}}{P_{01}} \\
& T_{0 x}=T_{01}+x * \Delta T_{0} \\
& \frac{T_{0 x}}{T_{01}}=1+x \times \frac{\Delta T_{0}}{T_{01}} \\
& \frac{T_{016}}{T_{0 x}}=1+(16-x) \times \frac{\Delta T_{0}}{T_{0 x}} \\
& \frac{T_{016}}{T_{0 x}}=1+(16-x) \times \frac{\frac{\Delta T_{0}}{T_{01}}}{\frac{T_{0 x}}{T_{01}}} \\
& \frac{T_{016}}{T_{0 x}}=1+(16-x) \times \frac{\frac{\Delta T_{0}}{T_{01}}}{1+x \times \frac{\Delta T_{0}}{T_{01}}} \\
& \frac{T_{016}}{T_{0 x}}=\frac{1+16 \frac{\Delta T_{0}}{T_{01}}}{1+x * \frac{\Delta T_{0}}{T_{01}}}
\end{aligned}
$$

$\frac{P_{016}}{P_{01}}=\left(\frac{T_{016}}{T_{0 x}}\right)^{\frac{\eta_{p}(k-1)}{k}} \times\left(\frac{T_{0 x}}{T_{01}}\right)^{\frac{\eta_{p}(k-1)}{k}}$

$$
\frac{P_{016}}{P_{01}}=\left(\frac{1+16 \frac{\Delta T_{0}}{T_{01}}}{1+x * \frac{\Delta T_{0}}{T_{01}}}\right)^{\frac{\eta_{p}(k-1)}{k}} \times\left(1+x \times \frac{\Delta T_{0}}{T_{01}}\right)^{\frac{\eta_{p}(k-1)}{k}}
$$


Compressor Work input:

$W_{c b} \dot{=} \frac{c_{p a} \times m_{a} \times\left(T_{0 x}-T_{1}\right)+c_{p a} \times\left(m_{a}-\dot{m}_{b}\right) \times\left(T_{016}-T_{0 x}\right)}{\eta_{c}}$

Turbine Work output:

$\dot{W}_{t b}=\left(c_{p g} \times \dot{m}_{g}+c_{p a} \times \dot{m}_{b}\right) \times \eta_{t} \times\left(T_{3}-T_{4}\right)$

Steam turbine work output:

$\dot{W}_{s b}=\dot{m}_{s} \times\left(h_{7}-h_{8}\right)$

Energetic efficiency of gas turbine power plant:

$\eta_{1 b}=\frac{W_{t b}-W_{c b}+W_{s b}}{\dot{Q}_{J}}$

Exergetic efficiency of gas turbine unit:

$$
\eta_{2 b}=\frac{W_{t b}-W_{c b}^{\dot{*}}}{\chi}=\frac{W_{t b}-W_{c b}}{\left(1-\frac{T_{0}}{T_{k}}\right) \dot{Q}_{J}}
$$

Exergetic efficiency of Combined cycle unit:

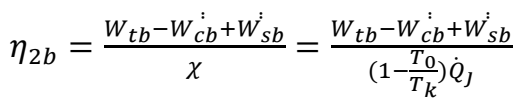

\section{RESUlTS AND DisCUSSION}

Fig. 3 shows the variation of both exergetic and energetic efficiencies with compressor inlet temperature for different values of turbine inlet temperatures for simple gas turbine operation of the plant. The full lines in the figure depict the variation of energetic efficiency whereas the dotted lines show the variation of exergetic efficiency. The variation demonstrates that both these efficiencies decrease with the increase in compressor inlet temperature and the decrease becomes steeper after the compressor inlet temperature of $200{ }^{\circ} \mathrm{C}$. Further these efficiencies show a consistent increase with the increase in turbine inlet temperature. Also the exergetic efficiencies are lower than the energetic efficiencies for all compressor inlet temperatures and at all turbine inlet temperatures. Fig. 4 demonstrates the effect of compressor pressure ratio on the energetic and exergetic efficiency of the gas turbine. A decrease in these efficiencies is found with the increase in the pressure ratio. It seems to be due to overburden of the compressor at higher pressure ratios which results in degraded performance of the gas turbine system.

Fig. 5 and 6 demonstrate the effect of change in Compressor inlet temperature on energetic efficiency (Fig. 5) and exergetic efficiency (Fig. 6) for different turbine inlet temperatures in both simple gas turbine and combined cycle operation of the unit. The full lines in the both figures are for the gas turbine operation whereas dotted lines are for combined cycle operation of the plant. From the variations it is observed that both energetic and exergetic efficiencies show an increase near the compressor inlet temperature of $200{ }^{\circ} \mathrm{C}$ and then decrease as this temperature increases. Further an increase in both types of efficiencies is observed with the increase the turbine inlet temperature in these operations. In these variations the efficiencies of combined cycle mode are seen to be higher as more work output is possible due to utilization of excess heat at the exit of the gas turbine.

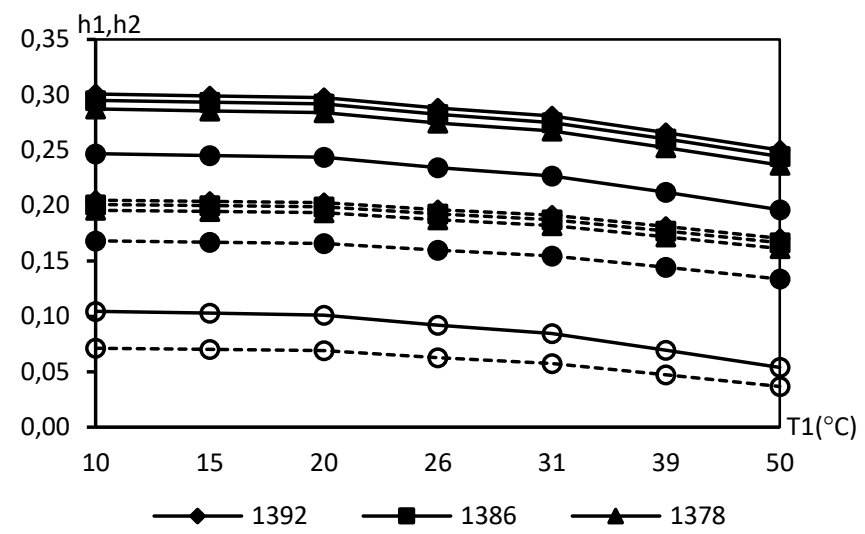

Fig. 3. Variation of energetic and exergetic efficiency of gas turbine with compressor inlet temperature for different turbine inlet temperatures. (Full lines $\eta_{1}$ and dashed lines $\eta_{2}$ ).

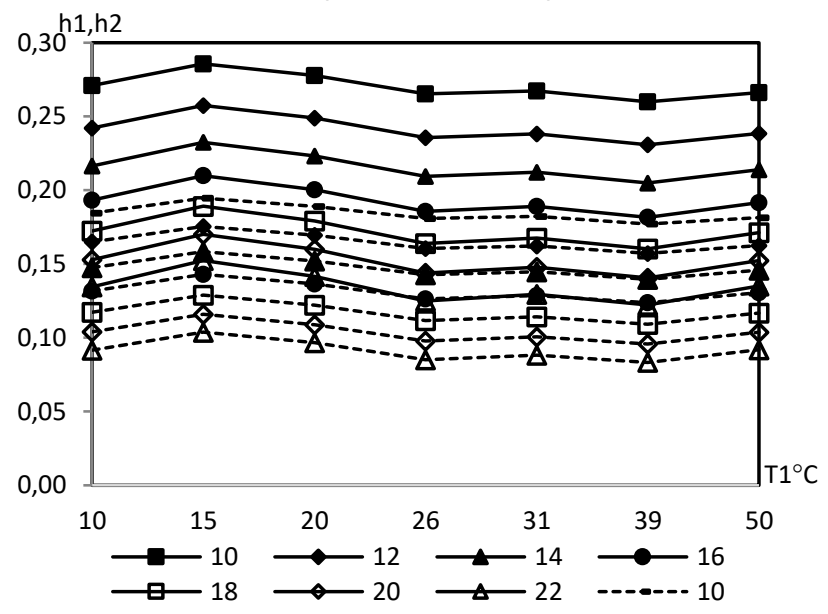

Fig. 4 Variation of energetic and exergetic efficiency of gas turbine with compressor inlet temperature for different compressor pressure ratios. (Full lines $\eta_{1}$ and dashed lines $\eta_{2}$ ).

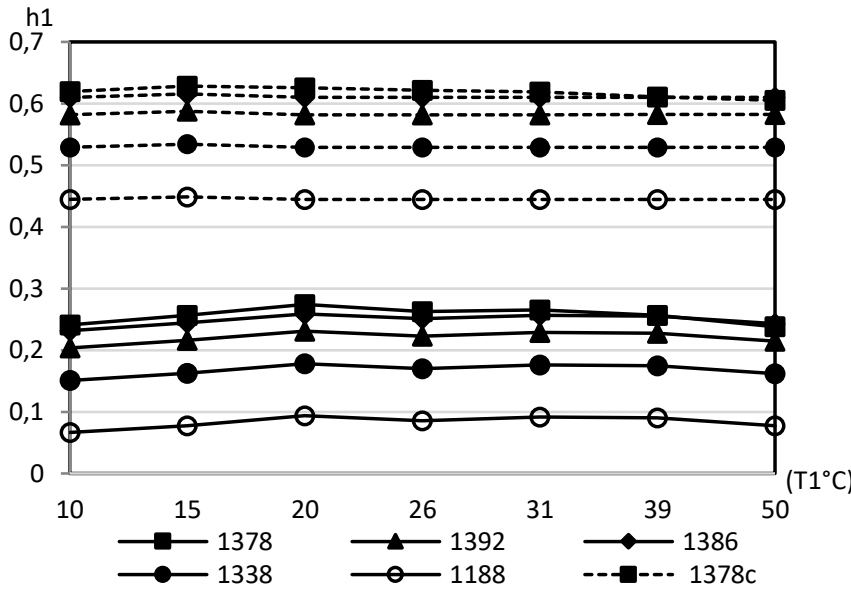

Fig. 5. Variation of Energetic efficiency of gas turbine (Full lines) and combined cycle (Dashed Lines) operation with Compressor inlet temperature for different Turbine inlet temperatures. 


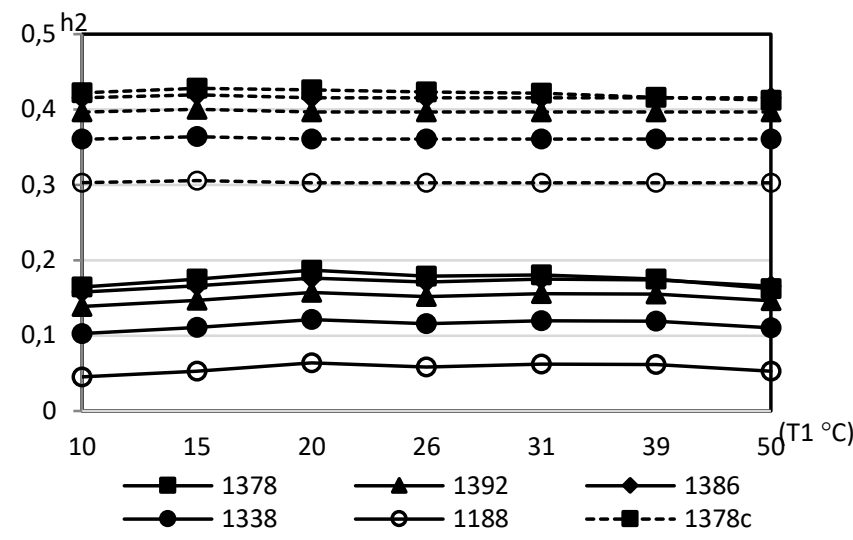

Fig. 6. Variation of exergetic efficiency of gas turbine (Full lines) and combined cycle (Dashed Lines) operation with Compressor inlet temperature for different Turbine inlet temperatures.

Fig. 7 presents the effect of compressor inlet temperature on the amount of steam produced in HRSG for different values of turbine inlet temperatures. It is observed that compressor inlet temperature has a small effect on amount of steam produced as against the turbine inlet temperature. A similar result is observed in Fig. (8) where effect of turbine inlet temperature is shown. This variation demonstrates that turbine inlet temperature has a significant effect of steam produced by HRSG compared to that of compressor inlet temperature. The change in compressor inlet temperature increases the amount of steam produced by $5 \%$ at the most whereas change in turbine inlet temperature increases it by about $35 \%$ for the given range of TIT. Fig. 9 shows the variation of the thermal efficiency of heat recovery steam generator with compressor inlet temperature for different turbine inlet temperatures. It depicts that the compressor inlet temperature has no effect on the efficiency of HRSG. About two percent variation is observed in case of turbine inlet temperature of $1378 \mathrm{~K}$. The turbine inlet temperature increases the efficiency of HRSG by $9 \%$ in the range of the values of turbine inlet temperature.

Fig. 10 and 11 demonstrate the effect of change in pressure ratio of the compressor on exergetic and energetic efficiencies of the gas turbine cycle operation and combined cycle operation of the unit for different compressor inlet temperatures. The full lines in the both figures are for the gas turbine operation whereas dotted lines are for combined cycle operation of the unit. Both the figures depict that as the pressure ratio increases both the efficiencies for both types of operations decrease. Further both types of efficiencies also show decrease with the increase in compressor inlet temperatures. Further as expected the efficiencies in combined mode of operation are higher than that of simple gas turbine operation. In the range of pressures ratios for the power plant under study the variation is shown in Fig. 12 which also depicts the same trends in the variation of the efficiencies for both cases of operation of the plant for the compressor inlet temperature of $200{ }^{\circ} \mathrm{C}$. In this figure the full lines are for the simple gas turbine operation of the unit whereas dashed lines are for the combined cycle operation of the unit.

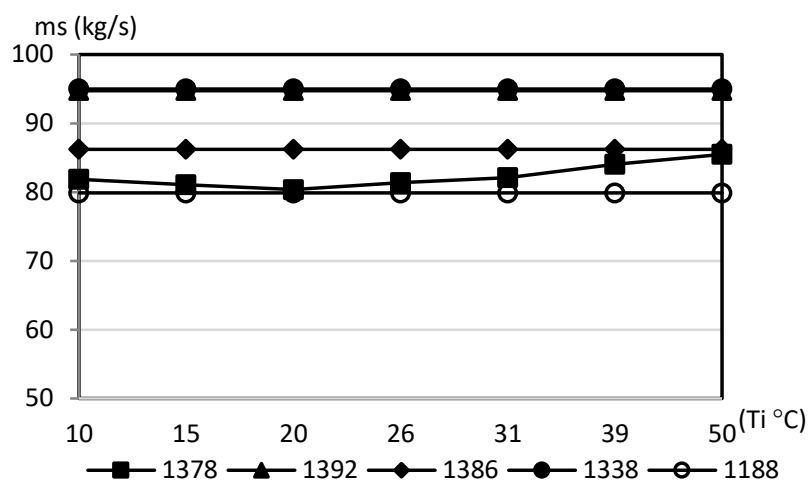

Fig. 7. Variation of steam produced in the combined cycle operation with Compressor inlet temperature for different Turbine inlet temperatures. $\mathrm{ms}(\mathrm{kg} / \mathrm{s})$

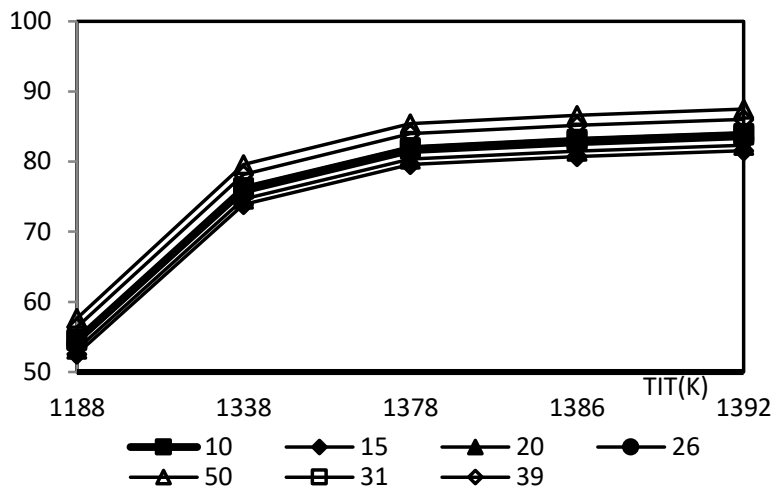

Fig. 8. Variation of steam produced in the combined cycle operation with Turbine inlet temperatures for different Compressor inlet temperature.

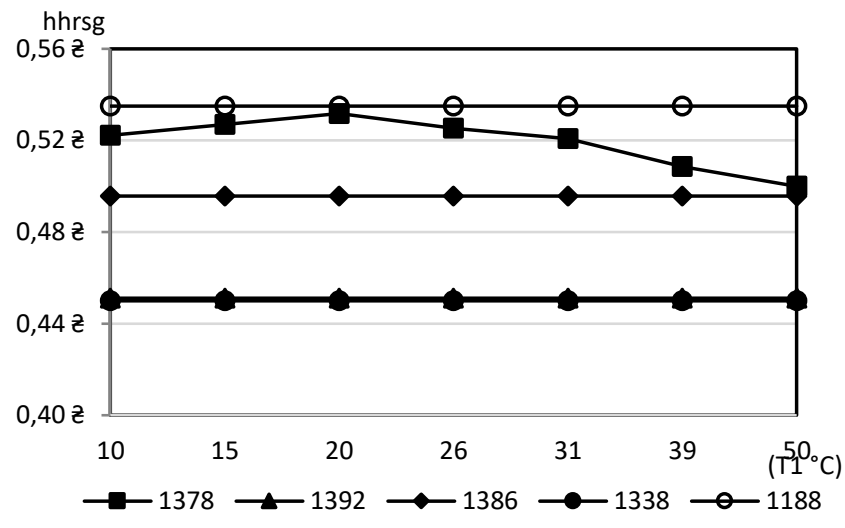

Fig. 9. Variation of efficiency of steam generator with Compressor inlet temperature for different Turbine inlet temperatures.

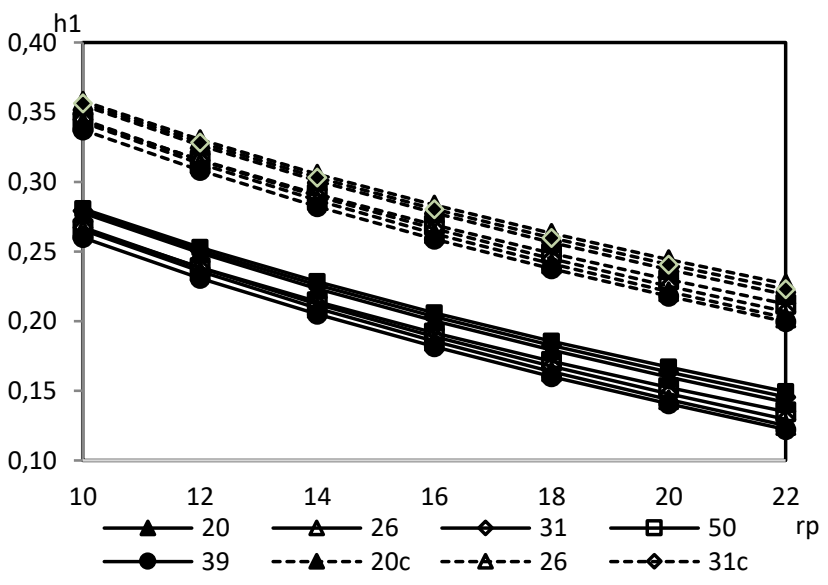

Fig. 10. Variation of energetic efficiency with compressor pressure ratios for different compressor inlet temperature in gas turbine (Full Lines) and combined cycle (Dashed Lines) operation of the plant. 


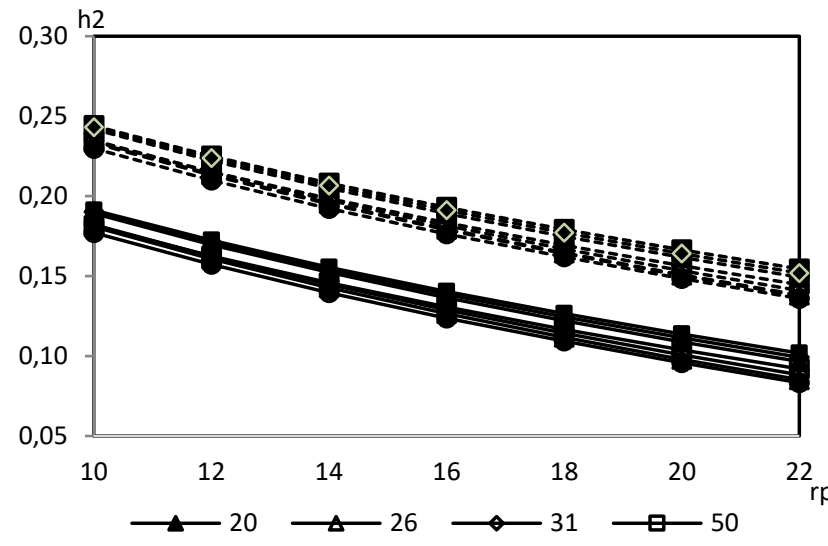

Fig. 11. Variation of exergetic efficiency with compressor pressure ratios for different compressor inlet temperature in gas turbine (Full Lines) and combined cycle (Dashed Lines) operation of the plant.

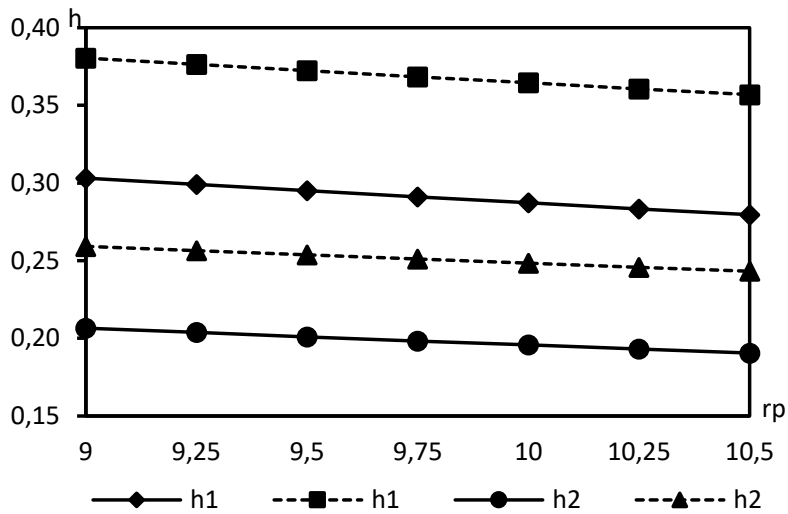

Fig. 12. Variation of energetic and exergetic efficiency of gas turbine with compressor pressure ratios in gas turbine and combined operation of the plant for compressor inlet temperature of $20^{\circ} \mathrm{C}$.

Fig. 13 presents the variation of energetic and exergetic efficiency with compressor inlet temperature for $1 \%$ bleed off air from different stages of the axial compressor. The full lines show the energetic efficiency whereas dashed lines are for exergetic efficiency. A decrease in both the efficiencies with increase in compressor inlet temperature is observed with a sudden increase for the compressor inlet temperature of $200{ }^{\circ} \mathrm{C}$. It is found that these efficiencies increase when the bleed off takes places from higher stations. Which happens because the compressor power input decreases with bleed off taken from higher stages. Fig. 14 shows the effect of increase in the percentage of bleed off air on the energetic and exergetic efficiencies of the unit. The bleed of has been taken from the second stage of the axial compressor. It shows a slight increase in the efficiencies up to compressor inlet temperature of $200{ }^{\circ} \mathrm{C}$ followed by a gradual decrease with the further increase in the compressor inlet temperature. The increase in the bleed off air percentage increases both the energetic and exergetic efficiencies.

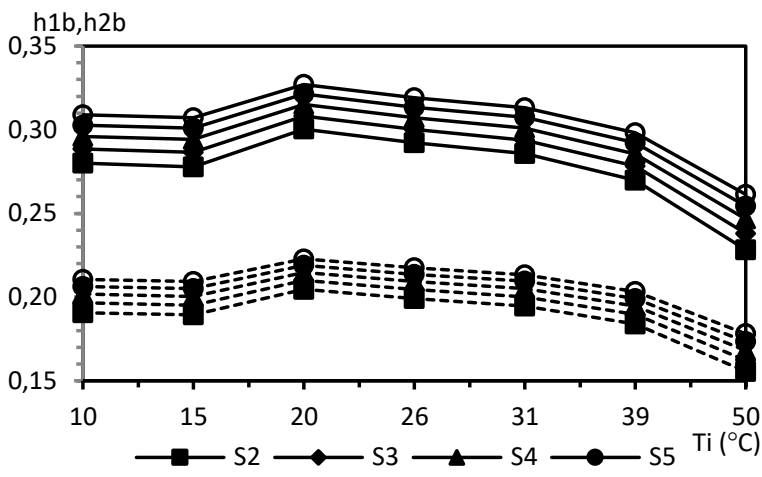

Fig. 13. Variation of energetic (Full Lines) and exergetic efficiencies (Dashed Lines) with Compressor inlet temperature for $1 \%$ bleed off air from different axial compressor stages.

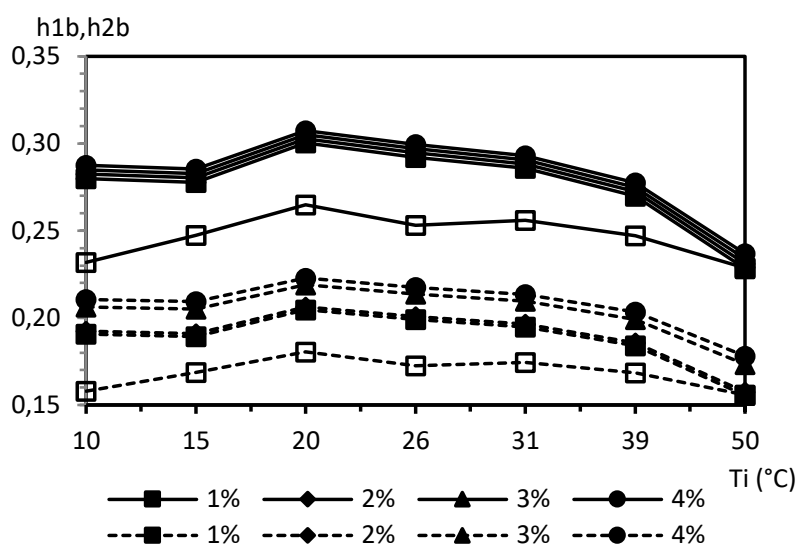

Fig. 14. Variation of energetic (Full Lines) and exergetic (Dashed Lines) efficiencies with Compressor inlet temperature with different percentages of bleed off air from second stage of axial compressor.

\section{CONCLUSIONS}

The following are the main conclusions drawn from the study,

1. Both energetic and exergetic efficiencies of gas turbine cycle and combined cycle decrease with increase in compressor inlet temperature and pressure ratio with a small peak at about $20^{\circ} \mathrm{C}$.

2. The increase in pressure ratio for different conditions of co turbine inlet temperature shows a decrease for both types of cycles.

3. The steam produced by the HRSG and its efficiency is more influenced by turbine inlet temperature than the compressor inlet temperature.

4. Both energetic and exergetic efficiencies depict increase with the increase in percentage of bleed off air and increase is more if the bleed off takes place at higher stages.

3. The steam produced by the HRSG and its efficiency is more influenced by turbine inlet temperature than the compressor inlet temperature.

4. Both energetic and exergetic efficiencies depict increase with the increase in percentage of bleed off air and increase is more if the bleed off takes place at higher stages.

\section{ACKNOWLEDGEMENT:}

The authors wish to thank Saudi Electric Company for allowing the visit to their power plant and shearing some of their performance data. 


\section{DECLARATION OF CONFLICTING INTERESTS}

The authors declare that they have no known competing financial interests or personal relationships that could have appeared to influence the work reported in this paper.

\section{REFERENCES}

[1] Jabber, J.O, Mohsen, M.S, Probert, S.D., Alees, M., "Future Electricity Demands and Greenhouse Gas Emissions in Jordan" Applied Energy, 2001, Vol. 69, 1-18.

[2] Najjar, Y. S. H., "Enhancement of Performance of the Gas Turbine Engines by Inlet Air Cooling and Cogeneration System" Applied Thermal Engineering, 1996, Vol. 16, 163-173.

[3] Jabber, J. O, "Greenhouse Gas Emissions and Barriers to Implementation in the Jordanian Energy Sector" Energy Policy, 2002, Vol. 30, 385-395.

[4] Abdurrahman, M. A and Abdulhadi, V. "A Review of Inlet Air Cooling technologies for Enhancing the Performance of combustion Turbines in Saudi Arabia" Applied Thermal Engineering, 2010, 30 1879-1888.

[5] Dixon, S. L. and Hall, C. A. "Fluid Mechanics and Thermodynamics of Turbomachines" 6th Edition, Butterworth- Heinemann, 2010.

[6] Alhazmy, M. M. and Najjar, Y. S. H., "Augmentation of Gas Turbine Performance Using Air Coolers" Applied Thermal Engineering, 2004, Vol. 24, 415-429.

[7] Amel, F. Cadavid, J., "Influence of the Relative Humidity on the Air Cooling Thermal Load in Gas Turbine Power Plant (2002)" Applied Thermal Engineering, 2002, Vol. 22, 1529-1533.

[8] 4 Al-Bortmany, J. N. "Assessment of equa-amonia refrigeration on pre-cooling gas turbine inlet air" Proceedings ASME TURBO EXPO 2002, Amsterdam, Netherland, June 3-6, 2002.

[9] Jaber, J. O., Badran, O. O, and Abu-Shikhah, N., "Sustainable energy and environmental impact: role of renewables as clean and secure source of energy for the 21st century in Jordan". Clean Technologies and Environment Policy, 2004, Vol. 6, 174-186.

[10] Franco, A. and Casarosa, C., "Thermo- economic Evaluation of the Feasibility of the Highly Efficient Combined Cycle Power Plants" Energy, 2004, 29, 1963-1982

[11] Villella, I. A. C and Silveira, J. "Ecological Efficiency in Thermoelectric Power Plants" Applied Thermal Engineering, 2007 27 840-847.

[12] Godoy, E., Scenna, N. J. and Benz, S. J. "Families of Optimal Thermodynamic solutions for the Combined Cycle Gas Turbine (CCGT) Power Plants" Applied Thermal Engineering, 2010, 30, 569576.

[13] Ogaji, S.T, "computer Simulation model for Industrial Gas Turbine Performance", Master Thesis, Department of Mechanical Engineering, river State University of Port Harcourt Press, Port Harcourt. (1997).

[14] Pankaj, K.P, "Better Power Generation from Gas Turbine along with Improved Heat rate", Proceeding of the 2003 Powergen international Conference, Atlanta, 1(3), pp1-6.

[15] Somkiat, B. and Pichia, N. "Exergy Evaluation of the EGAT Combined Power Plant, Proceedings of the 2004 Joint Conference on Sustainable Energy and Environment, Hua Hin, 4(4), pp 1-5.

[16] Mohamad, J.E. and Mofid, G. B., "Exergetic Analysis of Gas Turbine Power Plants, International Journal of Energy, 2005, 2(1) pp 31-39.

[17] Nasser, M. J. "Exergy Analysis and Second Law Efficiency of Regenerative Brayton Cycle with Isothermal Heat, Technical Paper, Entropy Pub, Amman Jordan, 7(3), pp 172-1787, 2005.

[18] Kamal, N. A. and Zuhair, A. M., "Enhancing Gas turbine output through Inlet Air Cooling" Sudan Engineering Society Journal, 52(46), pp 1-8, 2006.

[19] Tamer, Y., "Performance Optimization of Gas Turbine Based Cogeneration System, Journal of Physics, 39 (11) pp 2454-2458, 2006.

[20] Sanjay, O, Muku, A. and Rajay, Y., "Energy and Exergy Analysis of Brayton - Diesel cycle, Proceedings of the 2009 world Congress on Engineering, London, 2(1) pp 1-6.

[21] Ashok, K., Kachhwaha, S. S. and Mishra, R. S. "Thermodynamic Analysis of a Regenerative Gas Turbine Cogeneration Plant, Journal of Scientific and Industrial Research, 2010, 69(1) pp 225-231.

[22] Rosen, M. a. and Dincer, I., "Exergy as Confluence of Energy, Environment and Sustainable Development" Exergy International Journal, 1(1) pp 3-13 2001.

[23] Haseli, Y., Dincer, I. and Naterer, G. F., "Unified Approach to Exergy, Efficiency, Environment Impact and Sustainable Power Development for Standard Thermodynamic Cycles" International Journal of Green Energy, 5, 105-119, 2008.

[24] Saleh, S.B., Jamal, O. and Ansary, H. "Impact of ambient conditions of Arab Gulf countries on the performance of gas turbines using energy and exergy analysis" Applied Thermal Engineering, 138, 417 432.

[25] Abam, D.P.S. and Moses, N.N., "Computer Simulation of a Gas Turbine Performance" Global Journal of Researches in Engineering, Volume 11, Issue 1, 2011.

[26] Saravanamuttoo, H.I.H, Rogers, G.F.C and Cohen, H., (2001) "Gas Turbine Theory" 5th Edition, Pearson, Prentice Hall, London,2001.

\section{NOMENCLATURE}

$\mathrm{C}_{\mathrm{p}} \quad$ Specific heat $\mathrm{kJ} / \mathrm{kg}-\mathrm{K} \mathrm{kJ} / \mathrm{kg}-\mathrm{K}$

$\mathrm{C}_{\mathrm{pa}} \quad$ Average specific heat at constant pressure for air, $\mathrm{kJ} / \mathrm{kg}-\mathrm{K}$

$\mathrm{C}_{\mathrm{pg}} \quad$ Average specific heat at constant pressure for gases, $\mathrm{kJ} / \mathrm{kg}-\mathrm{K}$

h Enthalpy, $\mathrm{kJ} / \mathrm{kg}$

$\mathrm{k} \quad$ Ratio of specific heats

$\dot{m} \quad$ Mass flow rate, $\mathrm{kg} / \mathrm{s}$

$\dot{m}_{a} \quad$ Mass flow rate of air, $\mathrm{kg} / \mathrm{s}$

$\dot{m}_{b} \quad$ Mass flow rate of bleed of air, $\mathrm{kg} / \mathrm{s}$

$\dot{m}_{f} \quad$ Mass flow rate of fuel, $\mathrm{kg} / \mathrm{s}$

$\dot{m}_{g} \quad$ Mass flow rate of gas, $\mathrm{kg} / \mathrm{s}$

$\dot{m}_{s} \quad$ mass flow rate of steam $\mathrm{kg} / \mathrm{s}$

Pressure, $\mathrm{kPa}$

Heat supplied by fuel, $\mathrm{kJ} / \mathrm{s}$

Heating Value of fuel, $\mathrm{kj} / \mathrm{kg}$

Stage of the compressor (S2 Second Stage, etc)

Entropy, $\mathrm{kJ} / \mathrm{kg}$

Temperature, ${ }^{\circ} \mathrm{C}$

Ambient temperature ${ }^{0} \mathrm{C}$

Temperature of fuel gases ${ }^{0} \mathrm{C}$

Net power input of the Compressor, $\mathrm{kW}$

Net power output of combined power unit, $\mathrm{kW}$

Net power output of gas turbine unit $\mathrm{kW}$

Net power output of steam turbine $\mathrm{kW}$

$W_{t} \quad$ Net power output of gas turbine $\mathrm{kW}$ Greek Letters

$\eta_{c} \quad$ Isentropic efficiency of compressor

$\eta_{\mathrm{pc}} \quad$ Polytrophic efficiency of compressor

$\eta_{\mathrm{pt}} \quad$ Polytrophic efficiency of compressor

$\eta_{\mathrm{t}} \quad$ Isentropic efficiency of turbine

$\eta_{1} \quad$ Energetic efficiency of gas turbine power plant unit

$\eta_{2} \quad$ Exergetic efficiency of combined cycle power plant

$\chi_{f} \quad$ Exergy input

Subscript

$2 s$

$4 \mathrm{~s}$

Isentropic value of pressure or temperature at exit of compressor Isentropic value of pressure or temperature at exit of gas turbine

Ox Stagnation value of pressure or temperature at a stage of bleed off

air $\quad$ stage at which bleed off takes place

$\mathrm{x}$
$1 \quad$ Stage at which bleed off takes place
3

3 Gas turbine inlet 4 Gas turbine outlet

$7 \quad$ Inlet of HRSG 8 Exit of HRSG

01 Stagnation value of pressure or temperature at the inlet of compressor

016 Stagnation value of pressure or temperature at the exit of compressor 